\title{
Doing theology in multi-world contexts
}

\begin{tabular}{|c|c|}
\hline \multicolumn{2}{|c|}{$\begin{array}{l}\text { Author: } \\
\text { Johann-Albrecht Meylahn }{ }^{1} \text { (I) }\end{array}$} \\
\hline \multicolumn{2}{|c|}{$\begin{array}{l}\text { Affiliation: } \\
{ }^{1} \text { Department Practical } \\
\text { Theology, Faculty of } \\
\text { Theology, University of } \\
\text { Pretoria, South Africa }\end{array}$} \\
\hline \multicolumn{2}{|c|}{$\begin{array}{l}\text { Research Project Registration: } \\
\text { Project Leader: J.A. Meylahn } \\
\text { Project Number: } 02187133\end{array}$} \\
\hline \multicolumn{2}{|c|}{$\begin{array}{l}\text { Description: } \\
\text { This research is part of the } \\
\text { project, 'Towards a practic } \\
\text { postfoundational theology } \\
\text { public theology in respons } \\
\text { to the challenges of lived } \\
\text { religion in contemporary } \\
\text { Southern Africa', directed } \\
\text { by Prof. Dr J.A. Meylahn, } \\
\text { Department Practical } \\
\text { Theology, Faculty of } \\
\text { Theology, University of } \\
\text { Pretoria. }\end{array}$} \\
\hline \multicolumn{2}{|c|}{$\begin{array}{l}\text { Corresponding author: } \\
\text { Johann-Albrecht Meylahn, } \\
\text { johann.meylahn@up.ac.za }\end{array}$} \\
\hline \multicolumn{2}{|c|}{$\begin{array}{l}\text { Received: } 15 \text { Aug. } 2016 \\
\text { Accepted: } 27 \text { Jan. } 2017 \\
\text { Published: } 06 \text { July } 2017\end{array}$} \\
\hline \multicolumn{2}{|c|}{$\begin{array}{l}\text { How to cite this article: } \\
\text { Meylahn, J-A., 2017, 'Doing } \\
\text { theology in multi-world } \\
\text { contexts', HTS Teologiese } \\
\text { Studies/Theological Studies } \\
\text { 73(2), a3839. https://doi.org/ } \\
\text { 10.4102/hts.v73i2.3839 }\end{array}$} \\
\hline \multicolumn{2}{|c|}{$\begin{array}{l}\text { Copyright: } \\
\text { (c) 2017. The Author } \\
\text { Licensee: AOSIS. This } \\
\text { is licensed under the } \\
\text { Creative Commons } \\
\text { Attribution License. }\end{array}$} \\
\hline \multicolumn{2}{|l|}{ Read online: } \\
\hline 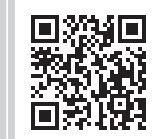 & $\begin{array}{l}\text { Scan this QR } \\
\text { code with your } \\
\text { smart phone or } \\
\text { mobile device } \\
\text { to read online. }\end{array}$ \\
\hline
\end{tabular}

This article seeks to respond to the challenge of doing theology in multi-world contexts, by understanding how these multiple worlds appear. Understanding the role of power in the appearance of these different worlds helps in the deconstruction of dominant worlds, but it leaves one with relativism, and consequently apathy. The article presents a Christo-fiction as a praxis of doing theology in multi-worlds as a way beyond such relativism.

\section{A paradigm for doing Theology}

This article is a response to the questions: What does it mean to do theology in a specific context, especially if the context is a multi-world context, like, for example, South Africa? What kind of thinking (epistemology) is necessary for contextual theology, where the context is characterised by multiple cultures and a plurality of views, which I call multi-world contexts?

What kind of epistemological space is necessary for doing theology in a context or with a context, where the practical theologian can be understood as a theologian with-in (with and in and within) differing contexts or differing worlds of that specific geographical space?

I would like to offer a few suggestions, not an exhaustive list, of what might be useful to take into consideration, when thinking about such a possible epistemological paradigm:

- The paradigm needs to be sensitive to the differences in contexts. In a context like South Africa with its diversity (cultural, economic, social, political, racial, religious, etc.) that would mean that even if one shares the same geographical space, that does not translate into sharing the same world. That is, if world is understood as that which is carried out (revealed) by language, or that which comes to light through language, the world view determines what kind of world comes to view. A different world comes to view depending on the particular world view of the individual or community, and because one does not share the same world view, the worlds that do come to view are very different. Therefore, there needs to be a sensitivity to the plurality of worlds depending on the plurality of world views in each geographical space. A paradigm is necessary that is sensitive to the plurality of worlds, as well as shifting worlds, as individuals transit between worlds throughout the day (work-world, family-world, friendsand-leisure-world, religious-cultural-world, digital-world and social media world).

- The paradigm needs to be radically hermeneutical ${ }^{1}$ (Caputo 1987; 2000). To be radically hermeneutical is not just to be aware of the need for interpretation, but that all there is are texts (Derrida 1997:158), and therefore, all there is are interpretations of interpretations. Everything can be read as a text (Ricoeur 1973:91), and consequently, everything needs and is interpretation: biblical texts, stories of individual lives, congregational stories, the community stories, the country's stories, the social-economic-cultural stories of the community, the political stories, the spiritual stories and the stories of science and technology. Together with an awareness that all there is are texts (interpretations) or stories, one has to be aware that there is never only a single interpretation or single story. What there might be is a dominant story, which presents itself as the only 'true' story and, therefore, as 'fact'. There is never only one story, but always multiple stories, and if given a chance to be heard, these multiple stories disrupt the dominant story. To every text, there is more than one interpretation, although there are often interpretations that have the necessary power to dominate, and therefore, it is the challenge of radical hermeneutics, or a narrative approach, to expose the power of dominant interpretations and create a space for alternative voices, or the voices of the Other and the other Other stories

1.My understanding I take from Caputo's interpretation of radical hermeneutics. That is the notion of hermeneutics with which I wish to begin: hermeneutics as an attempt to stick with the original difficulty of life, and not to betray it with metaphysics (Caputo 1987:1). A more radical hermeneutic does not mean some fanciful ability to make a clear, clean, or absolute start, to get back to some imaginary zero degree and to begin anew from there, which is the dream of idealists from Plato to G.W.F. Hegel, from René Descartes to Husserl, of philosophers from time immemorial. Rather, it confesses the necessity we are under to construe the traces, to follow tracks, to read signs. The hermeneutical situation means that we are up to our ears in historical, political, social, religious, sexual, and who knows what other sorts of structures and networks, saturated by them, radically saturated, which is, of course, another way for saying that we are all wet and not too sure what we know what is what (Caputo 2000:12). 
that need to be heard. There is always another other story that needs to be heard, and therefore, a radical hermeneutics or a narrative approach does not content itself with simple binaries or polarisations, such as SameOther, as there is always more than one Other that disrupts such simplistic binaries or polarisations, just as there is always difference within any Same.

- A sensitivity to the role of language in the appearing of worlds and the inability to escape language closes the door to search for underlying universal structures or essential truths, as whatever is found will only ever be one more interpretation. There can be no universal understanding or knowledge, only different interpretations. What is found are texts, which remain in need of interpretation, and therefore, the paradigm needs to be open to and aware of the multiple ways of interpreting knowledge and therefore interpreting texts. There is no universal human essence, no universal epistemology, but multiple epistemologies, reasoning strategies, ways of interpreting and therefore understanding. There is not just one way to interpret what it means to be human, not just one way to interpret what it means to be healthy, whole or normal, there is no singular or correct way to grieve or to overcome a crisis, although there will be experts in all these areas (see White 2011:xxviiif) offering over-psychologised expert knowledge that presents itself as the truth on all these matters.

Such a paradigm could possibly create an interesting space to be a theologian and to do theology in multi-cultural or, as I would like to argue, multi-world spaces. It is also a paradigm which could enable ethical thinking and acting, even if these different worlds are relative to their dominant narratives. I propose that these three bullets offer a starting point to think about a possible preferable paradigm for doing theology in multi-world contexts. To be able to do and to be a theologian in multi-world contexts, it seems obvious that one needs to be sensitive to the contextual differences. There are the obvious classical differences between rural and urban, or the differences between the different languages and cultural groups, the differences between different economic classes and the differences between the different racial groups. These are the traditional contextual differences, easily identified as these differences are often used to identify people. Everybody is aware that there is a difference between the world of the poor and the world of the rich, yet the different worlds we enter and leave in one day are not always that obvious, as in the world of the family and the world of work things often appear very different and consequently one responds differently. This explains why a business man in the business world can make certain decisions without thinking much about it, and yet struggle to make similar decisions, for example, when serving on a church board or congregational council.

The work world and the family-home world are different worlds, and it is within these worlds that experiences, events and phenomena are interpreted and made sense of. Each world forms the context, the world (Lichtung, clearing), in which the multitude of different stories of individual lives, family lives and community lives unfold. Events are emplotted in these worlds, worlds that are carried out by a certain muthos: dominant narrative. These are interpretation worlds in which events, experiences, phenomena find a home, that is, are interpreted and made sense of.

What is necessary to do theology in, in-the-midst and with these different worlds is the development of hermeneutical skills to be able to read a text within its contexts: read a text within its worlds. To read a text within its world without submitting such readings to what is often believed to be a critical reading, which is convinced that underlying truths or facts can be found. There is no non-interpretative access to the real world; there are only different interpretations that are always interpretations within specific worlds. The classical differentiation is the differentiation between interpretations within the world of myth and interpretations within the world of science. The scientific world view has become so dominant that its interpretations of things (texts) present themselves as presentations of the real over against the mythological interpretations.

All one ever finds, or rather interprets, are more texts (stories), maybe translating one story into the language of another world. So-called mythological stories might be translated into the language of psychology, but it is just a translation from one muthos to another, without that translation bringing one a single step closer to 'truth'. These translations are transitions from one world into another world.

Critical reading does not bring one closer to the truth, as it is only a translation from one world into another. That which was believed to be critical thinking of modernity has not been reached and will probably never be reached, as Bruno Latour (see Latour 1993) argues that we have never been modern. Thus, there are no myths and facts. All there is are different myths on the basis of which we have our beliefs about the world.

A sensitivity and appreciation for these different myths would prevent one from making any universal claims. It would also prevent one from the desire to reduce phenomena to singular and simple cause and effect reasoning, but rather take each and every story as a unique story, which can be interpreted within various and multiple worlds. Each unique story therefore offers endless possibilities of interpretations. Doing theology therefore is no longer to discover the truth or correct interpretation of a text (be it a biblical text or an individual or a congregation or the political-social-economic context as text), but rather an invitation to sojourn with those concerned through various worlds, each offering different interpretations, and together seeking preferred interpretations rather than 'true' interpretations, and thereby allowing preferred worlds to appear (see Freedman \& Combs 1996).

\section{A possible doing of Theology}

The praxis of Practical Theology, since Browning (1991:37f.), under the influence of Gadamer's hermeneutical method 
developed in Truth and Method (1982), has been understood as the fusion of horizons between Text and context. The praxis of a practical theologian is the conversation between Text (within worlds of interpretation - exegesis) and contexts (within worlds of interpretations) from the point of view of the reader's (theologian's) own specific context and story (worlds of interpretation), in view of the possible audience' worlds of interpretation, and therefore, a radical hermeneutics is necessary. A radical hermeneutics that takes all these worlds (texts within worlds of interpretation) seriously, not seeking correct interpretations, but if anything, preferred interpretations.

Is the doing of Theology or the doing of Contextual Theology a matter of the fusion of horizons (Gadamer 1982) between Text and context? That could translate into a critical exegetical reading of the Text and a critical reading or analysis of the context, bringing these two critical readings together, allowing them to fuse, that is, to interpret each other. In such a context (world), there would still be the possibility and therefore the desire to establish the 'correct' reading of both Text and context. Correct reading of the Text on the basis of the latest exegetical discoveries in New Testament and Old Testament studies, as well as the correct reading or analysis of the context on the basis of the insights gained from the latest development in the sciences (human, natural and economic) and their sub-disciplines.

The basic assumption of the pastoral hermeneutic cycle developed by Holland and Henriot and adapted for the South African context by Cochrane, De Gruchy and Peterson (1991:13-25), with its critical focus on context analysis, is that a context is analysable. This basic assumption, that a context can be analysed, with the use of various theories from diverse disciplines, just as an individual can be analysed in psychotherapy, is part and parcel of a specific world, namely a modern world, which places so much faith in the ability of the sciences to establish truth or correctness. The basic assumption is that a context can be read and not only read, but read correctly. Such an approach and interpretation of texts makes sense in a modern world, from a modern world view. It is a modernistic assumption that correct readings of texts and contexts can be offered, and on the basis of such correct reading, corrections can be made, either in psychotherapy (pastoral care) or in congregational studies.

A text or context is read correctly (truthfully) and critically, and on the basis of such a correct and critical reading, an appropriate (correct) therapy (pharmakon) or correction can be established and administered, so as to correct (remedy) the problem (often interpreted as an abnormality according to an established standard of what normality is). Such an approach falls within modernist thinking, which through thorough analysis underlying truths about individuals or contexts can be established, and once discovered, identified and classified, the correct pharmakon (medicine/therapy) can be applied and the result would be a cure: a correction of the problem. Whatever was not normal is brought back to normality or healing or wholeness in accordance with some or other interpretation of what the standard of normality, healing or wholeness is. Most research basically follows this pattern, which indicates that knowledge 'discovery' is still exclusively understood in these terms: a modern world. This explains why most research methodologies still follow this basic pattern of critical thought, which believes that it has the ability to discover truths (new knowledge).

The context is analysed on the basis of underlying economic, historical, political, cultural, religious, psychological and social theories that have the ability to offer 'truths' about the context or offer explanations (cause and effect) about the behaviour of individuals or communities or offer explanation of events (phenomena) in the context.

The pastoral cycle offers an analysis of the context so as to come to a correct understanding of the root of the problem, the cause of the problem (cause-effect reasoning). Such reasoning is highly valuable and therefore should not be discarded. On the contrary, there is probably no better reasoning. Therefore, what I am proposing is not anti-modern, but if anything modern, as it thinks modernity to its limits and becomes aware of these limits.

What this article is suggesting is not another form of reasoning or epistemology, but a sensitivity that all there is are interpretations. These interpretations (analyses) can offer only one possible interpretation and not the interpretation and that the same events, phenomena or texts, if read within different worlds, would offer totally different interpretations. In other words, I am not suggesting that one should move away from such reasoning, as such reasoning is all one currently has, and therefore, it is absolutely necessary. But equally necessary is a sensitivity to the insufficiency or nonfinality of such explanations (analyses), as they remain only one possible interpretation, which is dependent on that specific theoretical world. The paradigm that I am suggesting is not a new light (logos) and therefore not a new world view, but a sensitivity that each analysis offers only one possible and maybe even the best or most plausible interpretation. Yet, with a realisation that the best or the most plausible interpretation is not on the basis of truth, but on the basis of certain interests, the 'truth' or 'correctness' of interpretations has everything to do with power between the competing worlds, rather than with truthful (correct) representation of 'facts' (states of affairs). The role of power needs to be taken into consideration, and therefore, power is seen critically, but not negatively, as power necessarily plays a role in any interpretation.

Thus, the critical question that needs to be asked is: who benefits from a particular interpretation of a text or context. In all interpretations, power plays a role.

The various interpretations of the Marikana events clearly demonstrate the role of interest groups in the interpretation of events (see Meylahn 2014).

In the end, one does not have an accurate analysis of anything, but a particular person's or group's opinion on what is 
happening in an individual or in a community. All these differing opinions without a universal standard of truth (which in modernity was the accurate capture of reality) by which to judge them creates the symbolic misery, leaving citizens as a minority, with the danger that the loudest or most popular opinion will be followed. The opinion with the most political power, greatest number of supporters or the financial strength to influence the media and thus the 'argument' will win the day. I believe the Brexit vote in the UK and the 2016 presidential race in the USA illustrate to what extent economic and media power plays a role in influencing opinion.

To illustrate this paradigm, I will reflect on one of the debates that are currently dominant in numerous mainline churches, namely same-sex unions. One possible interpretation and maybe even dominant interpretation of this debate, although there are numerous other interpretations, is that the debate focuses on different hermeneutical approaches to reading biblical Texts. The way the debate is presented, in the public space, is that there are more or less two groups. One group is presented (appears) as arguing that the Texts on homosexuality need to be read within their social-cultural-historic-religious contexts and then brought into conversation with a critical reading or analysis of the contemporary context, listening to the various experts on human contemporary sexuality (e.g. Goss \& West 2000; Kessler 2004; Lings 2013; Stone 2001; Van der Walt 2016; Van Loggerenberg 2015). The other group is presented (appears) as arguing that the Bible is clear about these matters and that reading these Texts relative to their historical context undermines the authority and credibility of the Bible as such. It is this view that hetero-normative discourses with their truth claims as given and even as being universal (see Dreyer 2008:739; McLean, Carey \& White 1996:13). Different congregations of the same denomination, even different groups within the same congregation, are presented (appear) to be coming to opposing conclusions, although they are reading the same Texts, belong to the same denominational (exegetical) tradition and live in the 'same' modern scientific world, where the 'insights' from scientists and specialists are normally taken as the final authority. That these debates have become so divisive seems to indicate that there seem to be many more horizons that are playing a part in the conversation between Text and context. In other words, there seem to be multiple stories, narratives and discourses that are playing a role in interpreting these Texts and the contemporary context(s): in this case contemporary interpretations of human sexualities.

A fusion of horizons would make sense, and should be relatively easy to facilitate, if the meaning of a Text could be truthfully established as well as establishing the correct reading of the contemporary human sexuality. If a correct reading of both Text and context was possible, then all that would be necessary would be to find an expert on exegesis and an expert on contemporary human sexuality and bring them together: a fusion of horizons and problem solved. Yet, there is no correct reading of the Text, as a historical-critical exegetical reading is just one possible reading, which is dependent on a specific world view, with the belief that correct reading of a text can be established through thorough exegesis. The same world view believes that there is one correct understanding (forgetting that it is an interpretation) of contemporary human sexuality (forgetting that there is not just one kind of human sexuality, but very different interpretations of diverse sexualities). It might be that I myself am very comfortable and at home in such a world, where such readings of Texts and contexts are offered, yet I need to remind myself that such a reading of the contemporary context, as well as the historical-critical-reading of the Text, remains $a$ reading and as reading it is context-dependent (world-dependent). Such a critical ('liberal') reading is part of a very modernistic world view that believes that the true or correct meaning of a text can be offered through the lenses of various critical sciences. Such a reading makes sense within a specific modern appearing of humanity: a world view where insights from psychology, biology, sociology as well as insights from the historical-socio-cultural approaches to ancient texts are taken as the authority. A modernistic belief that truth can be found, correct interpretations can be established, and that insights can be offered, that is, to see inside, to see the essential (inside) truth of matters and to make those truths apparent (make them appear and visible to all, through clear logical scientific argument).

Yet, these insights remain only one possible sight, which is part and parcel of a particular world view, a very dominant and very powerful world view - which dictates most contemporary Western practices and therefore claims for itself to be self-evident and as such it is perceived to be as natural and logical as the air one breathes. What is not thought is that these insights are dependent on the light in which they come to view; in a different light they will come differently into view. What is not thought at all is that for light to come in, not only are cracks necessary, but a clearing (Lichtung) is necessary. The light indeed determines what comes to view, and in a different light different things come to view, but what is forgotten is the place (clearing) in which different lights allow different things to appear (see Heidegger 1961; 1977:383-384).

The liberal critical reading of Text and context is part of a particular modernistic world view (Light), but there are different world views, and in these debates, these world views clash.

The fusion of horizons is certainly something that happens, but it happens differently, depending on the different dominant world views in which such fusions take place.

The local pastor might have a certain world view formed during the years of study at a university, which is strongly influenced by liberal theological traditions, and therefore schooled in critical-historical readings of biblical Texts. This university narrative influences her reading of the 
Text and context. The congregation on the contrary might read the Text and context from a totally different world view, although they share the same (modernistic) world view on various other matters in their lives, but when it comes to matters of belief, morality and religion, they enter this specific world view. There are multiple worlds and often one moves from one world to another world numerous times a day.

It could become the task of the pastor to 'educate' or 'enlighten' the congregation into her world view, but on the grounds of what would she do that? On the basis of what criteria would one decide which world view is better or even argue that it is correct? The world view that is dominant and dictates most contemporary practices and has produced highly effective technologies may be a powerful and effective world view, but technological effectivity does not make it the only viable world view nor the correct world view (see Heidegger 1977:377). On the contrary, not being able to decide which is correct would leave one in a state of indecisive relativism between these multiple worlds.

Browning (1991:69ff.), in an attempt to move beyond such absolute relativism between world views, incorporated Habermas's $(1979: 2 ; 1984)$ four validity claims into his five validity claims of his Fundamental Practical Theology. These validity claims are very much part of a Western world view incorporating Western values and presenting these values as being universally applicable. The moment one has values or morals, one needs to be aware that values and morals are driven by a Wille zur Macht [will to power] of a particular interest group within a specific world view.

Any world view that is presented as being correct is based on some or other value judgement, which in turn is based on power, and who has the power to establish these values as legitimate or even universal and therefore as sovereign? If one could once more use the current debate in the mainline churches as an example - who has the power in society and church to establish certain values, the values of either having the moral high-ground to judge what is sin and what is not, or the moral high ground of being so enlightened and therefore accommodating of various sexual orientations? Whoever has the power will win the day, power in its various expressions: spiritual, moral, ecclesial, intellectual power or the strategic political power to mobilise the minority (convince the minority of your opinion) and thereby to create a numerical majority.

Thus, a simple fusion of horizons does not take the differences in world view into account and often presumes there to be only one universally valid or true world view of a single world (which is believed to be the world we all share). This single world view is often a positivist scientific modern world view, which is then taken to be the norm and the guiding measure of all things correct, better and true, 'as if we all live in the same world' and this view is the only sensible (logical) way of responding to what is believed to be the same world we all share. In the homosexual debate for example, the views of psychologists and historical-critical exegesis are taken as unquestionably correct or to be the more 'real' view of reality or at least the enlightened view of reality. It is enlightened, as light indeed has been cast onto the matter. It is enlightened to the degree that in that specific light in which it comes into view, it appears. It appears within and as the result of a particular light (logos). However, in a different light (logos) it would come into view differently.

The modernist representationalist view (logos or light) of the relationship between language and reality is so dominant that it has become for many unquestionable. It is taken for granted and seen as the only sensible norm for any debate or thought-process. What is forgotten in this modern-scientificcritical world is that it does not represent the world, but presents the world as exactly such a scientific world - it enlightens things to come into view. These enlightened things in turn carry out a particular enlightened world.

One therefore needs to move to the limits of Enlightenment and peer into the darkness or the abyss and realise that one is in the clearing (Lichtung) and whatever shares the clearing with one depends on what comes into view, what is enlightened by a particular light.

Thus, one shares the Lichtung with technological and scientific objects if the light that shines into the clearing is the light of modern science. One could also share the Lichtung with various creatures, spirits and divine revelations if a different light shines into the clearing.

Two different lights (logoi) or two different myths (Muthos) allow two very different worlds to appear. These different worlds are different because of the different lights (logos). The physics, the physical appearance of what is believed to be, the ontology of the clearing, depends on the meta-physics which allows the things (physics) to appear and thus what appears is dependent on a metaphysical decision or philosophical decision (see Laruelle 2010a; 2012).

\section{A radical hermeneutics and narrative}

In most major debates today, one is faced with a dead end; irrespective if the debate is about homosexuality or global warming, there is always more than one side to any of these stories. This can be highly frustrating, unless one perceives these multiple stories as being set in different worlds and within these worlds' different power groups. These worlds are competing and battling with each other, and there is no God's-eye-view beyond these differing worlds, to judge between these worlds, as to which is better or correct or even the true world. Such a situation would leave one in total relativity and consequently impotent, as one would be unable to make any ethical judgements as to what is good and what is evil, correct or false. The accusation of relativism is the obvious critique of such an approach, arguing that relativism leads to apathy or licentiousness. 
Although this critique is widespread, it is not the only interpretation of such an approach, as this approach can offer a very useful paradigm to think and consequently to act ethically; for example, an ethics of deconstruction (Critchley 1999). A radical hermeneutical approach deconstructs the competing moral judgements by reading them not on the basis of truth or knowledge of good and evil, but rather based on the power dynamics of groups between or within worlds. It is power that establishes truth and the ability to judge what is good and evil, and consequently correct moral practices, rather than the supposed true or correct representation of reality or 'facts'.

Narrative (White \& Epson 1990), being conscious of the role of power in interpretation of reality, focuses specifically on the marginal or shadow stories (the powerless) within any interpretation of reality, as in the margins, or outside the dominant view, there are alternative views (stories). These alternative views could provide openings for alternative and even preferred worlds. Deconstruction offers a democracy of thought, which is very different to the democracy of opinions. What one currently has in the West is a democracy of opinions, or as Alain Badiou calls it, democratic materialism (Badiou 2009:2), where there is nothing but bodies and languages. Badiou argues that this dualism should be broken open by a third element, which he calls truth (Badiou 2009:3). I would prefer to call it deconstruction or différance which breaks open democratic materialism, maybe for Badiou's (2009:3-4) materialist dialectic, and thus for the future.

Différance auto-deconstructs the dominant narratives that shape and determine the current worlds, by giving a space for the narratives hidden in the cracks of these dominant narratives to be heard. The idea that giving voice to marginalised voices might open a path towards preferred alternative worlds.

The idea of preferred realities raises the question, who decides what a preferred reality looks like? Does the idea of preferred realities not take one back to something similar to Habermas' validity claims, where one reality is claimed to be preferred (more valid) on the basis of a set of values? Who decides on these values?

A preferred reality is not chosen on the basis of values or validity claims, but by what is preferred. What is preferred is chosen by those concerned or affected by the preferred reality. In therapy, the question concerning a preferred reality is relatively easy to answer, as preferred is what is preferred by the client and those immediately affected by the client's world, for example, her or his family or community. The larger a community gets, the more diverse will be the opinions as to what is believed to be a preferred reality. What is, for example, a preferred reality for a city depends on who you ask. If you ask the wealthy $1 \%$, they would probably have a very different preferred city to those living in the cracks of the city. This would bring one back to relativity, different preferred realities and no way to judge between the different preferred realities.
Preferred realities would then again be established by power. The preferred reality which can muster enough emotional, social, economic, moral, spiritual, ecclesial and political power will be able to impose their view of a preferred reality on the rest.

\section{The strange hope placed in leadership}

If power plays such an important role, it makes absolute sense to focus on those in whom power is invested, namely leaders. This might explain a current dominant belief that all problems, political or institutional, can be solved by 'good' leadership, which explains the boom in leadership academies and programmes and the belief that MBA's can save the world, or at least manage it to happiness and success (according to a certain interpretation of what success and happiness is).

It makes sense, in a context of undecidable relativity, to turn to leaders who can lead a community out of this relativity. Yet, with what do they lead out of relativity? Leaders do not have access to truth; therefore, they have to rely on their rhetorical skills. This might explain the surge in populist movements throughout the world, where rhetoric alone seems to convince people, as has become evident in the Brexit vote or the presidential campaign in the United States (US) in 2016. Leaders, be they in church or political or business leaders, are implicated in the power struggles and are used by the dominant powers, which explains why - in a context of democratic materialism - democracy ends up being different forms of oligarchies.

A theology or a theological ethics that is based on the idea of needing to establish the truth of a matter (correct understanding or deeper insight into the matter) is playing the power game, as truth will be established by power and not a 'true' representation of the 'facts' or 'reality'.

\section{Discipleship?}

Is there a way beyond such relativism? Can theology offer a way forward? Is there a way to think on these different worlds with their opinions so as to enable ethical discernment? I would like to propose a following of Christ: discipleship - a following, which is not based on knowledge of Christ, as in a new Logos of Christ: Christology, but a practice: a way of being and doing. Following Christ as a way and a life, and as way and life: a truth - a truth beyond knowledge of good and evil, which can only be established by somebody's will to power. For that to happen, theology needs to rethink its relation to truth or its understanding of truth. Michel Henry (2003) offers some useful interpretations of Christ as truth - Christ as Life, and therefore not a transcendental truth, but an immanent truth.

A modernistic understanding of truth and correctness is too dependent on representationalist thinking, which has dominated most modern interpretations of truth: truth as 
that which can be factually (truthfully) presented, but what is forgotten is that any presentation is a re-presentation. In the so-called presentation of the 'facts' or in the presentation of the state of affairs, things are re-presented. The things are represented in language, thought, theory or argument, and together with language, thought, theory or argument comes the problem, that in the process of re-presenting through the medium of language (in its various forms), which was intended as a pharmakon [medicine] to capture reality or the state of affairs, this very pharmakon is also poison. The Gift of language is also the poison of language (see Derrida 1981:98-118). In any representational understanding of truth, there is death by poison. What is forgotten in the 'presenting' of facts is that 'facts' only come to view within a certain light and therefore are not presented, but re-presented within that light. The 'facts' are re-presented via copies (mimesis) in the form of words, concepts, formulas, equations and symbols, which only make sense if they are emplotted within a certain muthos - the muthos of a particular theory, logic, epistemology of the specific discipline that is (re)presenting the facts.

The different theologies, or Christologies, do the same with Christ. They re-present Christ. Therefore, I do not suggest a particular theology or Christology, but Christ alone who can offer a way, a truth and a life in the context of such deadends (death). Not a historical 'factual' Christ, as he could only appear within a historical-cultural-light of some or other tradition or school of interpretation. Thus, one should not try and seek a factual Christ, but rather consciously propose a fictional Christ, or a Christo-fiction (Laruelle 2015a). Simon Critchley (2012:91), in Faith of the Faithless, argues for a fiction that one is conscious of, 'a fiction that we know to be a fiction - there being nothing else - but in which we nevertheless believe'.

\section{Christo-fiction}

The Christo-Fiction that I am proposing is not only confined to the church, but its relevance is beyond the boundaries of Christianity, and therefore, one could speak of a public Christo-fiction, with the proviso: in the Western-influenced worlds. The reason for bringing Christ into any debate in Western-influenced worlds is that one cannot think the West, and the influences of the West in the global worlds, without thinking Christ (see Deleuze \& Guattari 2011; Nancy 2008; Taylor 2007). Thereby, I am not trying to establish a new form of Christian universalism, but rather trying to understand universalism from the perspective of its Christian roots (Badiou 2003). Western worlds appear to the White-man's Face, which is the Face of Christ, as argued by Deleuze and Guattari (2011:176f.).

Therefore, wherever the West in its various forms is, Christ is there as well; as long as the thinking is influenced by Western thought one inevitably thinks Christ. One might be totally unaware that one is inevitably thinking Christ, as one might be convinced that one is thinking from a secular perspective and yet Christ is unavoidably there. If Christ is already there in all these Western interpretations of reality, or if the Face of
Christ is the abstract machine (Deleuze \& Guattari 2011:168f.), the light that interprets or that allows these worlds to come to view, it would be useful and make sense to consciously think through Christ, but a thinking through Christ that is conscious that Christ will always be presented (re-presented) within a particular world. It remains an interpretation: Christ comes into view and is (re)presented within and by a certain light. What is necessary therefore is a fiction that is fully conscious that it is a fiction and is not one more attempt to present Christ, but conscious that it represents Christ. A Christo-fiction which has as its purpose not to present Christ, but to help think the various representations of Christ and the role these interpretations of Christ have played in creating the light (Logos) in which these different Western worlds appear.

Such a fiction might also open the possibility to think beyond opinion and relativity. For this to happen, this fiction needs to think the fictions of the abstract machine that create the light in which these different worlds appear. If the abstract machine of the West is the Face of Christ, then what is necessary is to think through Christ by creating such a Christo-fiction. Laruelle (2010b) attempts such a thinking through Christ with his Christ-science, by offering a scientific perspective on this abstract machine, with the question: why and how does the Face of Christ create the light in which these various Western worlds with their respective rationalities and reasoning strategies appear?

What about Christ appeared to Deleuze and Guattari that they interpreted the Face of Christ as the abstract machine of the West? There is a generic core to each of these different constructions of Christ, something that one could refer to as the messianic-core or the Christic-kernel, namely the three moments that are common to the various interpretations of Christ: incarnation, crucifixion and resurrection-ascension.

Incarnation - one possible interpretation of Christ's incarnation is that the incarnation is the incarnation either of the Greek logos or the Jewish Torah or various combinations thereof, which would mean that Christ is either the fulfilment of the Torah or the revelation of the Logos or various combinations and variations thereof. These two sign regimes (Greek Logos and Jewish Torah) are part and parcel of the various logoi in which Western worlds appear.

The crucifixion could then be interpreted as the world's rejection of this revelation as either the truth of the logos or fulfilment of the Torah. The resurrection and ascension could then be interpreted as the dialectical synthesis of the thesis and anti-thesis. This dialectical Christ again comes in various forms and traditions of differing rationalities and reasoning strategies.

In Laruelle's Christ-science (Laruelle 2010b), or Christo-fiction (2015a), he tries to read the Christic-kernel from a scientific perspective without attempting to offer a scientific Christology or theology, and certainly not a scientific Christ, but to understand how theologies and epistemologies are created via this Christic-kernel or Christ-apparatus and using 
metaphors from quantum science to interpret this. The way I read Laruelle, he is not emplotting Christ into a narrative of quantum physics, but he is borrowing concepts from quantum science to interpret the abstract machine of the West. In a sense, it is the construction of a conscious fiction of fictions, without seeking to construct the fiction or even a new fiction, but rather a praxis of being with-in various fictions.

In that sense, the Christo-fiction becomes the fiction to interpret differences (the different Western worlds), but without creating its own difference and therefore its own interpretation of reality.

The Christo-fiction offers an understanding of messianity, rather than a specific Messiah, and thus opens the door to faith rather than belief. It opens the door to messianity rather than a Messiah as it opens each one of these Christologies or epistemologies or reasoning strategies, firstly by viewing them as vectors produced by this abstract machine and therefore as Christologies, epistemologies that can co-exist equally with each other (superposition). These different epistemologies or world views are all equal as they are equally necessary but equally insufficient interpretations. It is this insufficiency that links up with messianity. Each of these Christologies, epistemologies and reasoning strategies are equally valid and not-valid, are equally necessary but insufficient as they are only fictions (possible interpretations). This insufficiency is not seen as a lack or a flaw or a sin which must be overcome by a specific messiah. It does not seek to place these interpretations into a context of a primal fall (sin) or teleological end (salvation), but it opens them to the future, endless future interpretations equally necessary and insufficient that are still to come. There is no trace of the Real (primary origin) nor traces of a teleological end, but vectors, different vectors and more vectors to come. The incarnation brings one to the democracy of thought, as all thoughts are equal (see Ó Maoilearca 2015). It is in this equality of thought, this democracy of thought, that makes all thoughts equally necessary but insufficient, that messianity is to be found. It is this insufficiency of thought that keeps thought open to the future to come.

The incarnation can be interpreted as these different vectors: vectorielle.

Crucifixion - the crucifixion is interesting in the Christofiction, as the crucifixion takes into account the role of power and normativity in the various interpretations. Christ is crucified by the dominant powers of the specific interpretations, because he is accused of blaspheming the dominant gods of these interpretations. In the historical time of Jesus of Nazareth, the two dominant powers or religions and ideologies were the Roman Ideology of the Pax Romana and the Pharisaic Law, which Jesus was disturbing through his association with the marginal whilst proclaiming an alternative kingdom to come. His association, as well as his parables and preaching, questioned the Law and its ability to bring about the kingdom, and questioned the peace of the Pax Romana. Jesus' action and preaching challenged the powers and therefore he had to be crucified. He was crucified as the ultimate criminal that blasphemed the legitimising powers of the two dominant interpretations of his context. One can imagine the trouble one would be in if one challenged the light in which not only the world appears but also the light that gives meaning and order to that world. It is this challenge that can only be interpreted as the ultimate criminal, because it ultimately challenges the whole world and its order, meaning and legitimisation.

In the Christo-fiction, Christ's association with the victims of dominant powers brought him into trouble with the dominant powers of the dominant interpretations. The temptation would be to emplot Jesus into specific narratives of liberation (as many liberation theologies have done) by associating Jesus with particular victims (slaves, blacks, women, children), but the victims cannot be specified in the Christofiction, and therefore, the focus is rather on a generic victim (Laruelle 2015b): maybe in the sense that the poor will always be amongst you (Jn 12:8). In the Christo-fiction, Jesus associates with the generic victim and thereby becomes the generic-ultimate criminal disrupting the dominant powers of whatever worlds.

Resurrection - the resurrection is the hope that arises from the new impossible possibility after the crucifixion of the dominant powers of the various worlds. Resurrection is therefore interpreted as the liberated life from the various dominant discourses of the different worlds. Yet, such a liberated discourse in its attempt to create community inevitably needs its own muthos, and therefore becomes a new world, which in time would be in need of liberation: ecclesia reformata, semper reformanda secundum verbum Dei.

This abstract fiction of the abstract machine is maybe what practical theology, practical Christology or practical Christofiction could be all about. To have faith in this Christo-fiction, following not Christ of some or other world (interpretation), but following Christ (Christo-fiction) and thereby becoming messianic, offering a messianic praxis of faith without any belief in a specific interpretation of Christ, but a messianic opening of the various worlds through association with the generic victim, who is always the specific victim in a particular world, with whom Christ associated and therefore was crucified, and the impossible possibility of resurrection life, liberated from whatever the powers are of the various worlds. One could therefore say that in life and death one is dependent on Christ alone and not on that which Christ does, nor that which Christ opens, but again and again dependent on Christ alone, on the Christo-fiction alone - which does its messianic work: crucifying the dominant logos of each world and creating a liberated space for new worlds to emerge.

\section{Doing Theology}

Doing Theology is to be a theologian. Therefore, one can agree with Browning (1991:47) that it is indeed a Fundamental Practical Theology as it has to do with what one is, which determines what one does. A narrative paradigm is not 
something to be applied, it is something to be, it is the way one is in the worlds, a way of reading the worlds, how one reads texts within contexts, and therefore, a way of doing and being a theologian or maybe doing and being a Christian. Narrative paradigm, or Christo-fiction, does not offer the practical theologian skills to be applied, but offers the practical theologian a paradigm to be a theologian (follower of Christ) and to do theology in multiple contexts (worlds), sensitive to the differences in worlds. Being sensitive that each of these different worlds comes into view determined by its world view (logos), without proposing an alternative world view, but proposing Christ-alone. Each world view creates an essential understanding of both world and humans inhabiting that world, offering its own specific ontological inventory of all beings of that world.

This sensitivity towards world views in which worlds come into view could easily be accused of being a dead-end of perspectivism and the consequent total relativity of everything. Each world view is as real as it gets; in fact, it gets no realer than these fictions, because it is in these fictions that we live. What is offered is a way to be in these real worlds, but opening these worlds to what is to come.

A Christo-fiction calls for faith and becoming messianic, rather than having a correct view of reality. Doing Theology, being a practical theology, is being faithful to the Christofiction and thereby becoming messianic. How does that translate into the current debate in the Church? How does being a Christian and doing theology translate into in this specific context? Doing theology, being messianic and remaining faithful to Christ and not believing in one or other Christology creates an interesting facilitating space between these different worlds with their different epistemologies and different Christologies. Seeing each for what they are: necessary but insufficient, without proposing an alternative, but calling for faithfulness to the Christo-fiction. This translates into being messianic - being with the marginal voices in the various power battles, thereby unifacially turning these worlds, not towards truth, nor towards another world, but towards an absolute future of the resurrection: an impossible possibility of liberated space, liberated from the dominant powers of the various worlds. It is a liberated resurrection space that is a deconstructed (crucified) space where the power of various logoi [world views] is deconstructed (crucified). The various logoi, be they political, racial, cultural, religious or sexual, are deconstructed and therefore space for new identities is created.

What does all this mean concretely? How does this translate into a decision concerning homosexuality in the church, for example? It translates into a ' $\mathrm{No}^{\prime}$ to the powerful gods of truth on both sides and 'Yes' to the future where there will be neither Greek nor Jew, man or woman, gay or straight, conservative or liberal. No to both sides of the various debates and yes to Christ. Yes to Christ incarnated in any world, associating with the victims of those worlds, so as to challenge the dominant powers of the various worlds and thereby cracking open previously impossible spaces.
Cracking open impossible possible spaces where identities, righteousness, correctness and normality are no longer dependent on the dominant world views, but where there is neither Jew, Greek, man, woman, free nor slave, but new liberated identities in Christ alone. A liberated identity in Christ is a crucified identity, as I know nothing but Christ alone and him crucified.

A deconstructed (crucified) identity where there is neither Jew nor Greek, in other words, where identity is no longer dependent on these worlds, carried out by certain dominant world views, which gives things and people a specific place within that world or exclude them from that world, creates an equality of crucified identities, but it needs to take past injustices into consideration, as it calls for the justice of the democracy of identities to come.

Practical Theology, as a calling of disciples to follow Christ in incarnation, as the incarnation of the love (God so loved the world that he gave is only Son). This love, by which disciples will be known, is not the love for family and friends, but the love for enemies. To love the enemies, one loves those that question the dominant narratives of the various worlds - the enemies are often the victims, those excluded by the norm of these worlds, as they challenge the light in which these worlds appear (see Meylahn 2010).

This following of Christ's incarnation leads to the crucifixion, challenging and cracking open the worlds, thus opening a space free that is non-determined by power interests. Henry (2003) argues that such would be Life. This is of course impossible, as there is nothing outside text, nothing appears without a world view, and therefore, following Christ is an endless following, never arriving, always remaining on the way. There is always a world view, so there will always be identity, be it cultural, political, racial or sexual identity, but what is different is that these identities are seen as necessary, but insufficient. They are seen as necessary and with the necessity comes the history, often painful history of certain identities (racial and sexual), which need to be always taken into consideration, but also the insufficiencies of these identities. The insufficiency creates a democracy of identities, a democracy of insufficiency. Yet, as identity is always necessary, the past and specifically the injustice of the past needs to be taken into consideration in the democracy of the insufficiency of identities, but without returning to the eternal return of the master-slave cycle.

The master-slave cycle is broken as it is not a new identity that drives this discipleship or messianic praxis, but faith alone in Christ, alone by the grace, alone by loving the enemy those excluded, who question the light in which the included come to view. It is this love (grace) that breaks open the confining and limiting norms of the worlds for what is impossible within the confines of those norms and therefore opening the worlds for the impossible. Christ opens such an impossible possible way (kingdom in our midst) that makes this praxis messianic: always towards that impossible space of the kingdom to come and of Life to come, through the 
continuous deconstruction of the constricting views through love for the victims of these world views.

With a Christo-fiction, you can go on no crusade, but it calls the practical theologian to faithfulness to Christ alone and messianic being and doing of this Christo-fiction.

\section{Acknowledgements Competing interests}

The author declares that he has no financial or personal relationships which may have inappropriately influenced him in writing this article.

\section{References}

Badiou, A., 2003, Saint Paul: The foundation of universalism, Stanford University Press, Stanford, CA.

Badiou, A., 2009, Logics of worlds: Being and event, 2, transl. A. Continuum, Toscano, London.

Browning, D.S., 1991, A Fundamental Practical Theology: Descriptive and strategic proposals, Fortress Press, Minneapolis, MN

Caputo, J.D., 1987, Radical hermeneutics: Repetition, deconstruction and the hermeneutic project, Indiana University Press, Bloomington, IN.

Caputo, J.D., 2000, More radical hermeneutics: On not knowing who we are, Indiana University Press, Bloomington, IN.

Cochrane, J.R., De Gruchy, J.W. \& Peterson, R., 1991., In word and in deed: Towards a practical theology for social transformation, Cluster Publications, Pietermaritzburg.

Critchley, S., 1999, The ethics of deconstruction: Derrida and Levinas, 2nd edn. Edinburgh University Press, Edinburgh.

Critchley, S., 2012, The faith of the faithless: Experiments in political theology, Verso, London.

Deleuze, G. \& Guattari F., 2011, Thousand plateaus: Capitalism and schizophrenia, transl. B. Massumi, University of Minnesota Press, Minneapolis, MN.

Derrida, J., 1981, Dissemination, transl. B. Johnson, Continuum, New York.

Derrida, J., 1997, Of grammatology, transl. G.C. Spivak, John Hopkins Press, Baltimore, MD.

Dreyer, Y., 2008, 'Pastoral care and gays against the background of same-sex relationships in the Umwelt of the New Testament', HTS Teologiese Studies/ Theological Studies 64(2), 739-765. http://dx.doi.org/10.4102/hts.v64i2.42

Freedman, J. \& Combs, G., 1996, Narrative therapy: The social construction of preferred realities, W.W. Norton \& Company.

Gadamer, H.-G., 1982, Truth and method, Crossroad, New York.

Goss, R.E. \& West, M. (eds.), 2000, Take back the Word: A Queer reading of the Bible, The Pilgrims Press, Cleveland, $\mathrm{OH}$.

Habermas, J., 1979, Communication and the evolution of society, Beacon Press, Boston, MA.

Habermas, J., 1984, The theory of communicative action 1. Reason and the rationalization of society, Polity Press, Cambridge.
Heidegger, M., 1961, Was Heist Denken? Zweite, unveränderte Auflage, Max Niemeyer Verlag, Tübingen.

Heidegger, M, 1977, 'The end of philosophy and the task of thinking', in M. Heidegger (ed.), Basic writings: From being and time (1927) to the task of thinking (1964), edited D.F. Krell, translated by J. Stambaugh, Harper San Francisco, San Francisco, CA.

Henry, M., 2003, I am the truth: Toward a philosophy of Christianity, Stanford University Press, Stanford, CA.

Kessler, R., 2004, 'From bipolar to multipolar understanding: Hermeneutical consequences of intercultural Bible reading,' in H. De Wit, L.C. Jonker, M. Kool \& D. Schipani (eds.), Through the eyes of another: Intercultural reading of the Bible, pp. 452-459, Institute for Mennonite studies, Elkhart, IN.

Laruelle, F., 2010a, Philosophies of difference: A critical introduction to non-philosophy, transl. R. Gangle, Continuum Books, London, Kindle edition.

Laruelle, F., 2010b, Future Christ: A lesson in heresy, transl. A.P. Smith, Continuum, London.

Laruelle, F., 2012, From decision to Heresy: Experiments in non-Standard thought Edited R. Mackay, Sequence Press, New York.

Laruelle, F., 2015a, Christo-fiction: The ruins of Athens and Jerusalem, transl. R. Mackay, Columbia University Press, New York.

Laruelle, F., 2015b, General theory of victims, transl. J. Hock \& A. Dubilet, Polity, Cambridge.

Latour, B., 1993, We have never been modern, transl. C. Porter, Harvard University Press, Cambridge, MA.

Lings, K.R., 2013, Love lost in translation: Homosexuality and the Bible, Trafford Publishing, Bloomington, IL.

McLean, C., Carey, M. \& White, C. (eds.), 1996, Men's ways of being, Westview Press, CO.

Meylahn, J.-A., 2010, 'Holistic redemptive pastoral ministry in the fragmented transit hall of existence', HTS Teologiese Studies/Theological Studies 66(1), Art. \#426, 1-9. http:/dx.doi.org/10.4102/hts.v66i1.426

Meylahn, J.-A., 2014, 'Imagining the beauty and hope of a colourful phoenix rising from the ashes of Marikana and service delivery protests: A postfoundational practical theological calling', HTS Teologiese Studies/Theological Studies 70(1), 1-6. http:/dx.doi.org/10.4102/hts.v70i1.2616

Nancy, J.-L., 2008, Dis-enclosure: The deconstruction of Christianity, transl. B. Bergo, G. Malenfant \& M.B. Smith, Fordham University Press, New York.

Ó Maoilearca, J., 2015, All thoughts are equal: Laruelle and nonhuman philosophy, University of Minnesota Press, Minneapolis, MN.

Ricoeur, P., 1973, 'The model of the text: Meaningful action considered as a text in New Literary History', vol. 5(1), in What is literature?, pp. 91-117, Autumn, John Hopkins University Press.

Stone, K. (ed.), 2001, Queer commentary and the Hebrew Bible, The Pilgrim Press, Cheveland, $\mathrm{OH}$.

Taylor, M.C., 2007, After God, kindle edition, University of Chicago Press, Chicago, IL.

Van der Walt, C., 2016, "Is "being right" more important than "being together"? Intercultural Bible reading and life-giving dialogue on homosexuality in the Dutch
Reformed Church, South Africa', in E. Chitando \& A. Van Klinken (eds.), Christianity Reformed Church, South Africa', in E. Chitando \& A. Van Klinken (eds.), Christianity
and controversies over homosexuality in contemporary Africa, pp. 125-137, and controversies
Routledge, Oxford.

Van Loggerenberg, M., 2015, 'The 2007 Dutch Reformed Church Synod resolution: Impact on gay ministers', HTS Teologiese Studies/Theological Studies 7(3), 1-9. http://dx.doi.org/10.4102/hts.v7i3.2894

White, M., 2011, Narrative practice: Continuing the conversations, W.W. Norton \& Company, Inc., New York.

White, M. \& Epston, D., 1990, Narrative means to therapeutic ends, Dulwich Centre, Adelaide. 